\title{
Effects of Physical Sputtering and Annealing Temperature on Surface Behaviourof Cu-10wt.\% Ni Alloy
}

\author{
H.N.Soliman ${ }^{a}$, H.M.Hosni ${ }^{b}$ and A.Rizk ${ }^{a}$ \\ ${ }^{a}$ Physics Department, Faculty of Education, Ain Shams University, \\ Roxy, Cairo, Egypt. \\ ${ }^{b}$ Solid State Physics Department, National Center for Radiation \\ Research and Technology, Nasr City, Cairo, Egypt.
}

\begin{abstract}
Effects of physical sputteringand annealing temperature on surface behaviour of $\mathrm{Cu}-10 \mathrm{wt} . \% \mathrm{Ni}$ alloywere studied using scanning electron microscopy, optical microscopy, X-ray diffraction, energy-dispersive X-ray spectroscopy and microhardness measurements. The results showed that surface topography and composition of the given alloy as well as its hardness were greatly affected by sputtering time and annealing temperature. It is worth noting that sputtering of the as-received samples up to $3 \mathrm{~h}$ increased the Ni content on the alloy surface by approximately53\% compared with the unsputtered sample, while sputtering the annealed samples (up to $1073 \mathrm{~K}$ for $1 \mathrm{~h}$ ) for $3 \mathrm{~h}$ increased the Ni content on the sample surface by approximately $32 \%$ compared with the as-received (unsputtered) sample. The increase of Ni content on the sample surface either due to sputteringor annealing temperature significantly enhances the resistance of the given alloy to erosion corrosion in flowing seawater and other aggressive waters.
\end{abstract}

\section{Introduction:}

Copper and nickel are closely related and completely miscible in both the liquid and solid states. $\mathrm{Cu}-\mathrm{Ni}$ alloys crystallise over the whole concentration range in a face-centred cubic lattice. $\mathrm{Cu}-\mathrm{Ni}$ alloys have interesting physical and mechanical properties, even under continuous loading and at elevated temperatures, together with high resistance to corrosion in many media, especially seawater [1,2]. An important application for the binary $\mathrm{Cu}-\mathrm{Ni}$ alloys is coinage [3,4]. The most ancient $\mathrm{Cu}-\mathrm{Ni}$ coin (that comes from the period around $\mathrm{BC} 235$ ) and many other old coins are outstanding examples for the high corrosion resistance of $\mathrm{Cu}-\mathrm{Ni}$ alloys. 
The essential areas of application of $\mathrm{Cu}-\mathrm{Ni}$ alloys are indicated by their high corrosion and erosion resistance in aqueous media. The corrosion resistance of these alloys relates to a stable protective coating on the surface due to the alloying metal (Ni). Therefore, $\mathrm{Cu}-\mathrm{Ni}$ alloys serve as materials for firewater systems, lifeboat cladding, etc ... as well as they are widely used for marine applications [5-9]. They have provided reliable service for several decades whilst offering effective solutions to todays technological challenges [10].

In particular, there are two main $\mathrm{Cu}-\mathrm{Ni}$ alloys used in marine service which are generally available in most product forms. These alloys are $\mathrm{Cu}-10 \mathrm{wt} . \% \mathrm{Ni}$ andCu-30wt.\% Ni which have good corrosion resistance even to hot seawater and at high flow rates [11-13]. The $\mathrm{Cu}-30 \mathrm{wt} . \% \mathrm{Ni}$ alloy is stronger and can withstand higher seawater velocities but, for most applications, the $\mathrm{Cu}-10 \mathrm{wt} . \% \mathrm{Ni}$ alloy provides good service at a lower cost and of the two alloys tends to be the one that is more widely used $[14,15]$.

It is worth noting that nickel has a significant effect on the interesting physical and mechanical properties of $\mathrm{Cu}-\mathrm{Ni}$ alloys. While tensile strength, $0.2 \%$ yield strength, hardness, solidus and liquidus temperature and corrosion resistance increase with nickel content, thermal and electrical conductivities decrease[16].

The changes in surface composition of $\mathrm{Cu}-\mathrm{Ni}$ alloys after various treatments have been observed by means of Auger electron spectroscopy [17-21]. The surface composition was found to be considerably changed from the bulk of alloy samples by the pre-treatments, namely the surfaces of the nickel-rich alloys are enriched with copper, while those of the copper-rich alloys are with nickel [18].

Based on a literature review and considering the above observations, this study aims to investigate the effects of physical sputteringand annealing temperature on surface behaviour (topography and composition) of $\mathrm{Cu}-10 \mathrm{wt} . \% \mathrm{Ni}$ alloy using scanning electron microscopy, optical microscopy, $\mathrm{X}$-ray diffraction, energy-dispersive X-ray spectroscopy and microhardness measurements. 


\section{Experimental Details:}

\subsection{Samples Preparation}

The $\mathrm{Cu}-10 \mathrm{wt} . \% \mathrm{Ni}$ alloy used in the present study was prepared from predetermined weights of spectroscopically pure copper and nickel metals by melting them in a vacuum silica tube. The method of preparation was described elsewhere [22]. The mixture was shaken mechanically at intervals and was held after each shake in the melt state then the tube was left to cool in air.

Homogenization was achieved by solutionizing the ingot at $873 \mathrm{~K}$ for $24 \mathrm{~h}$. The ingot was then cold rolled at a $10 \%$ reduction per pass to a final thickness of 0.25 mmwith intermediate steps of annealing during the rolling process. The elemental composition of the alloy under investigation was obtained as $\mathrm{Cu}-10 \mathrm{wt} . \% \mathrm{Ni}$ by using energy-dispersive $\mathrm{X}$-ray spectrometer. Fig.(1) shows the presence of $\mathrm{Cu}$ and $\mathrm{Ni}$ elements in the as-received $\mathrm{Cu}-10 \mathrm{wt} . \%$ Nisample. Samples undergoing the previous steps were polished to obtain the as-received material and some of them were transferred to a furnace for various heat treatments as will be explained below.

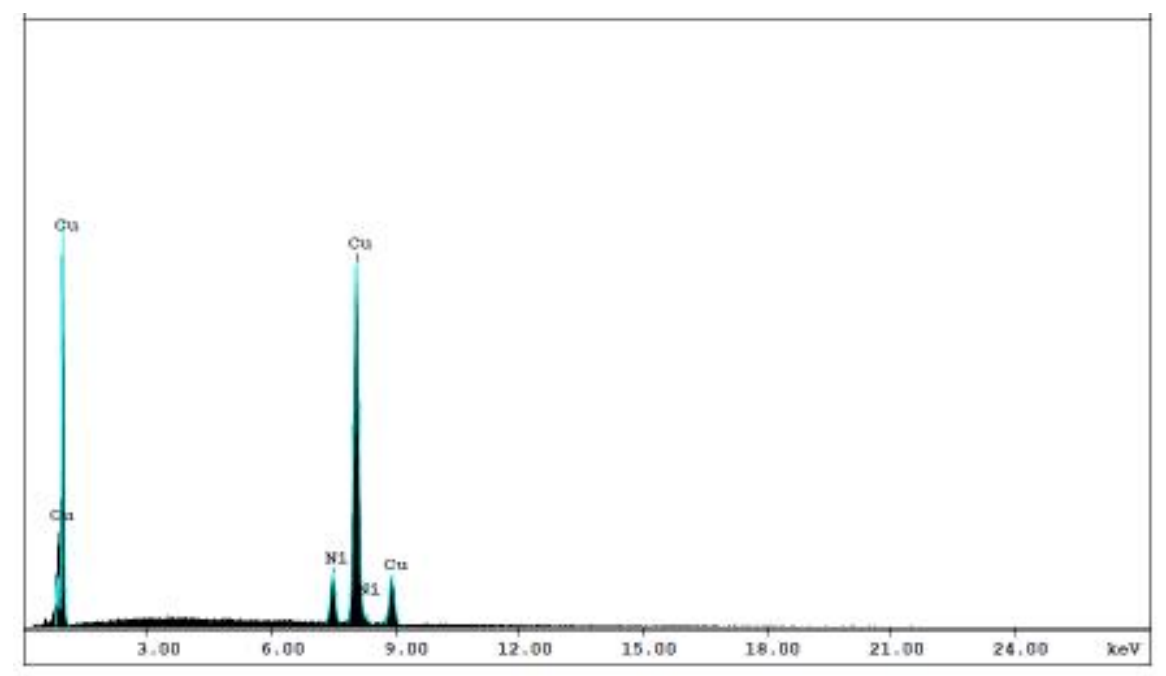

Fig. (1): EDX spectrum showing the different elements in the $\mathrm{Cu}-10 \mathrm{wt}$ \% $\mathrm{Ni}$ alloy.

\subsection{Heat Treatments and Characterization Techniques}

Samples of the Cu-10wt.\% Ni alloy $(1.5 \times 0.5 \mathrm{~cm})$ were cut and annealed in groups in the temperature range (473-1073 K) for $1 \mathrm{~h}$ followed by water quenching. All samples were electopolished to be ready for different 
analyses, measurements and examinations mentioned earlier. A solutionof 30 ml distilled $\mathrm{H}_{2} \mathrm{O}$ and $70 \mathrm{ml} \mathrm{H}_{3} \mathrm{PO}_{4}$ acid with a copper cathode was found appropriate for polishing the samples of the given alloy.

To reveal the grain boundaries, the electropolished samples were etched in a solution composed of $10 \mathrm{~g} \mathrm{FeCl}_{3}$ and $120 \mathrm{ml}$ distilled $\mathrm{H}_{2} \mathrm{O}$ in $30 \mathrm{ml} \mathrm{HCl}$ acid for $15 \mathrm{sec}$ [23]. Grain boundaries of the samples were observed using optical microscope (Model MF-AKS Photomicro graphic Equipment $24 \times 36$ AUTOMATIC-2). Determination of average grain size was determined using the standard linear intercept method. Additionally, phase analysis of the samples before and after the different annealing treatments was performed using X-ray diffractometry (Philips $X^{\prime}$ Pert Multi Purpose Diffraction Diffractometer). Filtered $\mathrm{CuK} \alpha$ radiation with a wavelength of $1.5406 \mathrm{X}$-ray diffraction (XRD) patterns over a wide range of diffraction angles $2 \theta$ ranging from $30^{\circ}$ to $100^{\circ}$ were recorded at room temperature.

Hardness measurements of this alloy were made with Vickers microhardness tester (Model MHP 160). A constant load of 80 gf for $30 \mathrm{~s}$ was found appropriate for this alloy. At least 15 indentations for each sample were considered to obtain accurate results.

Scanning electron microscopy equipped with an energy-dispersive X-ray spectrometer (EDS/EDAX Genesis FESEM/ QUANTAFEG 250, Central Metallurgical Research and Development Institute, El Tabbin, CairoEgypt) was used to examine the changes in surface topographies of the alloy samples as well as their surface compositions due to ionic bombardment.

\subsection{Sputtering Experiments}

Sputtering experiments were performed using a d.c. magnetron sputtering system (Balzers SCD 040) which has been described in detail elsewhere [24]. A Cu-10wt.\% Ni disc of $5.4 \mathrm{~cm}$ diameter was used as a target. This target was electopolished (in a solution mentioned earlier) then cleaned in ethyl alcohol and distilled $\mathrm{H}_{2} \mathrm{O}$ before sputtering experiments. The vacuum system evacuated to an ultimate pressure of $0.1 \mathrm{~Pa}$ before gas admission using a two-stage rotary pump with a pumping speed of $4 \mathrm{~m}^{3} / \mathrm{h}$. Argon gas of 99.999\% purity was employed to the vacuum system through a copper coil immersed in liquid nitrogen before admission to the vessel to remove water vapour and $\mathrm{P}_{2} \mathrm{O}_{5}$ was used as a drying agent inside the vessel. The Argon pressure during sputtering was $10 \mathrm{~Pa}$ while voltage and current were $460 \mathrm{~V}$ and $45 \mathrm{~mA}$, respectively. The samples were sputtered separately for different 
times ( $1 \mathrm{~h}, 2 \mathrm{~h}$ and $3 \mathrm{~h}$ ). Furthermore, the temperature of the samples was kept constant (at about $303 \mathrm{~K}$ ) during sputtering process since they were placed on a cooled target. Therefore, no diffusion occurred during the sputtering process.

\section{Results and Discussion:}

\subsection{Surface Topography}

\subsubsection{Effect of sputtering time on the as-received samples}

It is interesting to notice the effect of increasing sputtering time on the surface topography of the as-received polished samples. The surface morphology of the as-received polished sample is given as a reference. The morphological features developed on surfaces of the sputtered samples for different times ( $1 \mathrm{~h}, 2 \mathrm{~h}$ and $3 \mathrm{~h}$ ) are shown in Fig. (2). As can be seen from Fig. (2), the surface of the as-received (unsputtered) sample appeared almost smooth and free from any isolated particles (plate a). As the sample was sputtered for $1 \mathrm{~h}$, nano particles (average particle size less than $100 \mathrm{~nm}$ ) are observed all over the surface of the sample (plate b).
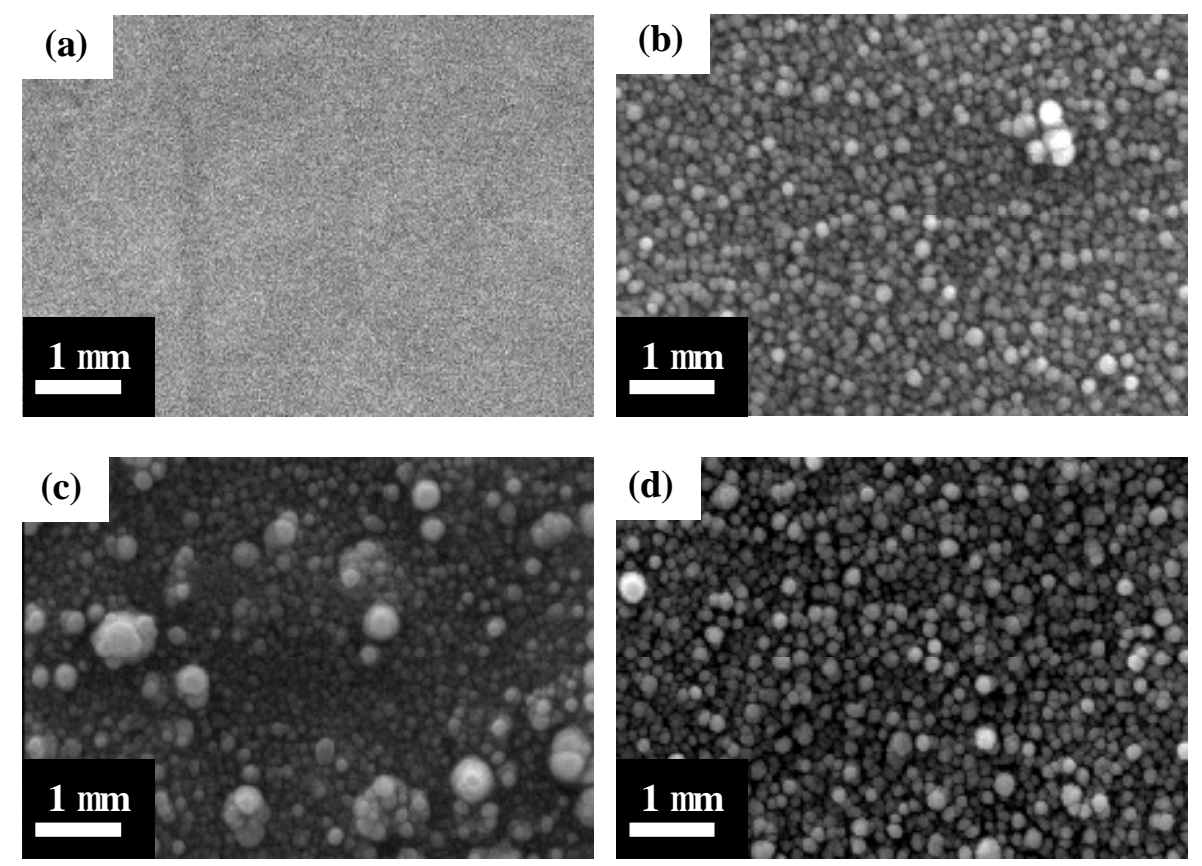

Fig. (2): Surface morphology of the as-received $\mathrm{Cu}-10 \mathrm{wt} . \% \mathrm{Ni}$ samples developed in $\mathrm{Ar}^{+}$d.c. glow discharge for: (a) $0 \mathrm{~h}$ (unsputtered); (b) $1 \mathrm{~h}$; (c) $2 \mathrm{~h}$; (d) $3 \mathrm{~h}$. 
As the sputtering time increased to $2 \mathrm{~h}$, the surface became slightly eroded with the appearance of some tiny cones (plate c). Further increase in sputtering time up to $3 \mathrm{~h}$ resulted in the disappearance of the tiny cones and the sputtered surface appeared fully covered with nano particles again (plate d). These particles are identical to those formed in plate (b).

This cyclic changes can be referred to the presence of particles with different sputtering yields. As the sputtering time increased to $2 \mathrm{~h}$, some particles (of high sputtering yield) are sputtered off leading to a partial depletion of the surface, and the other particles (of low sputtering yield) are appeared as tiny cones, (place c). As the sputtering time increased to $3 \mathrm{~h}$, the tiny cones are sputtered off and new particles are appeared again in the depleted regions as shown in plate (d).

On the other hand, the number of sputtered monolayer's per second per $\mathrm{cm}^{2}$ of the sputtered sample was calculated and found to be approximately 12 monolayer's which have a thickness of 31 Á then EDS analysis was used to detect the elemental compositions at different sputtering times and depths as shown in section 3.2.

\subsubsection{Effect of ion bombardment on thermally annealed samples}

Samples of average grain sizes $8 \pm 0.5,14.5 \pm 1$ and $43.5 \pm 4.5 \mu \mathrm{m}$ (Fig. 3a-c) were obtained by annealing the samples in the temperatures 873 , 973 and $1073 \mathrm{~K}$, respectively. Annealing twins were observed in the grains (Fig. 3c). On the other hand, the average grain sizes of samples that annealed at temperatures less than $873 \mathrm{~K}$ could not be measured optically.

Different annealed $\mathrm{Cu}-10 \mathrm{wt} . \% \mathrm{Ni}$ samples were sputtered separately in argon d.c. glow discharge for $3 \mathrm{~h}$. Fig. (4) shows the surface morphological features due to ion bombardment for the annealed samples in the temperature range (473-1073 K) for $1 \mathrm{~h}$. As can be seen from Fig.(4), scattered tiny particles are observed all over the surface of the sample (plate a) that annealed at $473 \mathrm{~K}$. As annealing temperature increased up to $673 \mathrm{~K}$ (plate $\mathrm{b}$ ), the surface became slightly more eroded with the appearance of bit larger particles. Further increase in annealing temperature up to $873 \mathrm{~K}$ and $1073 \mathrm{~K}$, respectively (plates c,d) resulted in the formation of particles which were gathered in semicircular shapes (plate c) and the appearance of large cones (plate d).

In general, it can be seen that sputtering of the annealed $\mathrm{Cu}-10 \mathrm{wt} . \% \mathrm{Ni}$ sample at $1073 \mathrm{~K}$ (plate d) produced an irregular surface associated with the appearance of large cones and etch pits which increased the total surface area. These morphological features are believed to be due to 
the growth of more particles of the meta-stable $\mathrm{Cu}_{3.8} \mathrm{Ni}$ phase which believed to be of low sputtering yield. These observations are, however, supported by the XRD analysis given in Fig. 5 (a-c) which confirms the growth of $\mathrm{Cu}_{3.8} \mathrm{Ni}$ phase when the samples were annealed at previously mentioned temperatures than this for the as-received (unannealed) sample.
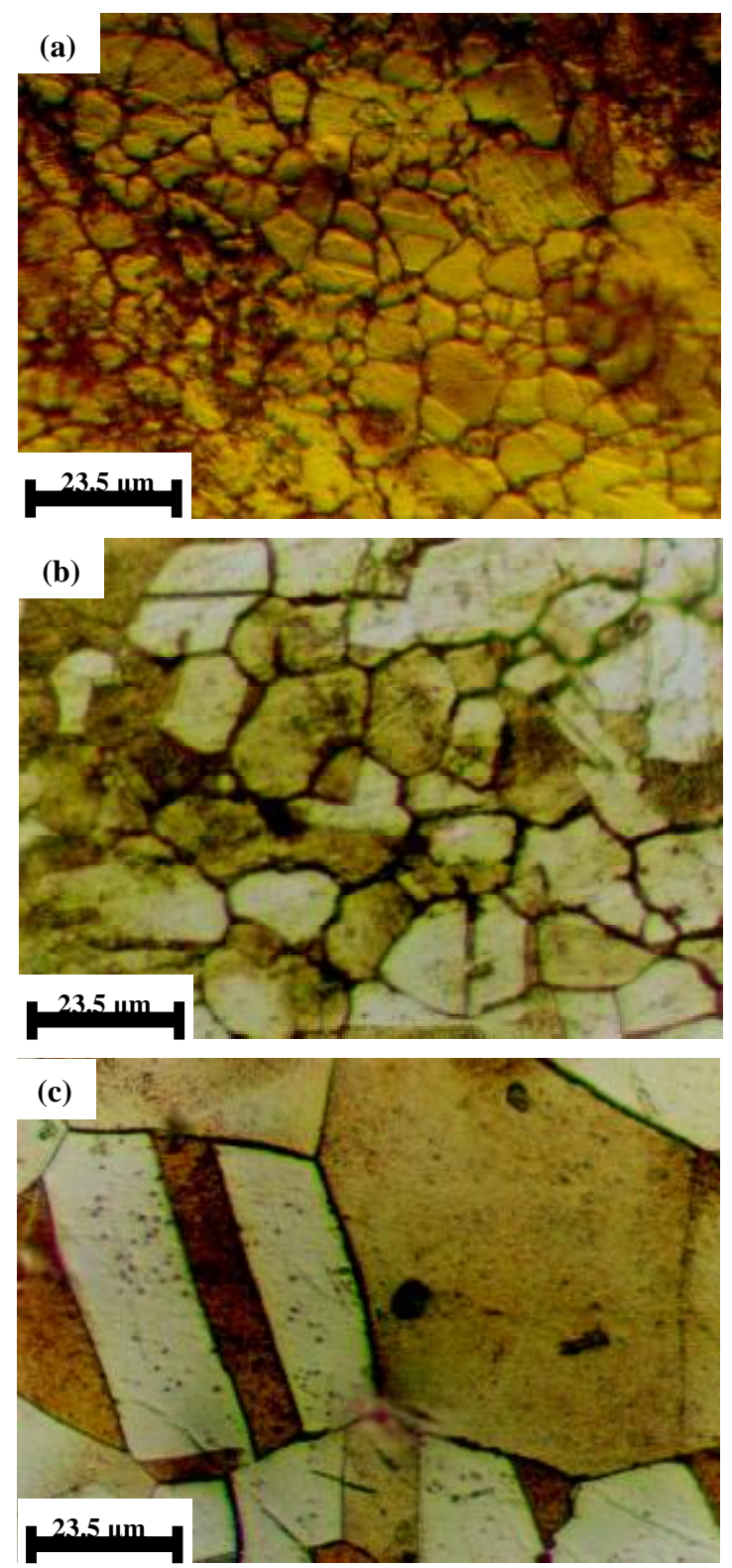

Fig. (3): Grain sizes of $\mathrm{Cu}-10 \mathrm{wt}$. $\% \mathrm{Ni}$ alloy annealed for $1 \mathrm{~h}$ at the temperatures 873, 973 and $1073 \mathrm{~K}$ : (a) $8 \mu \mathrm{m}$; (b) $14.5 \mu \mathrm{m}$; (c) $43.5 \mu \mathrm{m}$. 

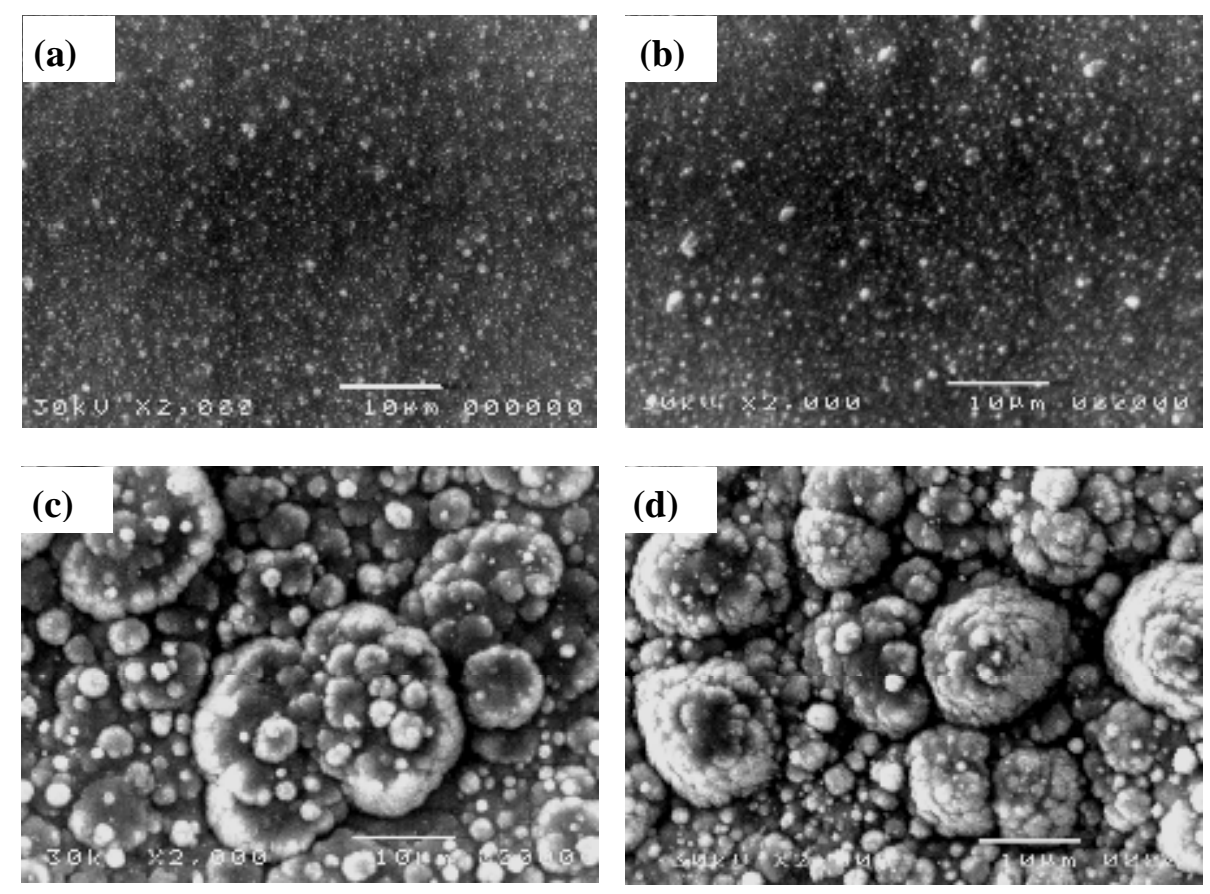

Fig. (4): Surface morphology of the $\mathrm{Cu}-10 \mathrm{wt} . \% \mathrm{Ni}$ samples due to $\mathrm{Ar}^{+}$sputtering for $3 \mathrm{~h}$ after annealing the samples for $1 \mathrm{~h}$ at different temperatures: (a) 473
K; (b) $673 \mathrm{~K}$;
(c) $873 \mathrm{~K}$; (d) $1073 \mathrm{~K}$.

The growth of the $\mathrm{Cu}_{3.8} \mathrm{Ni}$ phase associated with increasing the annealing temperature is confirmed by calculating the particle size $(\mathrm{t})$ from the half width of the spectral lines corresponding to $\mathrm{Cu}_{3.8} \mathrm{Ni}$ phase using Scherer formula [25]:

$$
t-\frac{k \lambda}{B \cos \theta}
$$

where:

$\boldsymbol{k}$ is the Scherrer's constant (=0.9),

$\lambda$ is the wavelength of the $X$-ray,

$\boldsymbol{B}$ is the line broadening at half the maximum intensity (FWHM) (in radians),

$\theta$ is the Bragg diffraction angle.

The changes in the average particle size of $\mathrm{Cu}_{3.8} \mathrm{Niphaseassociated} \mathrm{with}$ increasing the annealing temperature are summarized in Table (1). It is to be noted from Table (1) that the particle sizes of $\mathrm{Cu}_{3.8} \mathrm{Niphase}$ are on the average of $23.8 \mathrm{~nm}$ for the as-received sample. As annealing temperature increased up to $673 \mathrm{~K}$, the average particle sizes are slightly increased to be $26.3 \mathrm{~nm}$. Increasing the annealing temperature up to $1073 \mathrm{~K}$ resulted in significant increase in the average particle sizes $(41.8 \mathrm{~nm})$ due to their growth. 


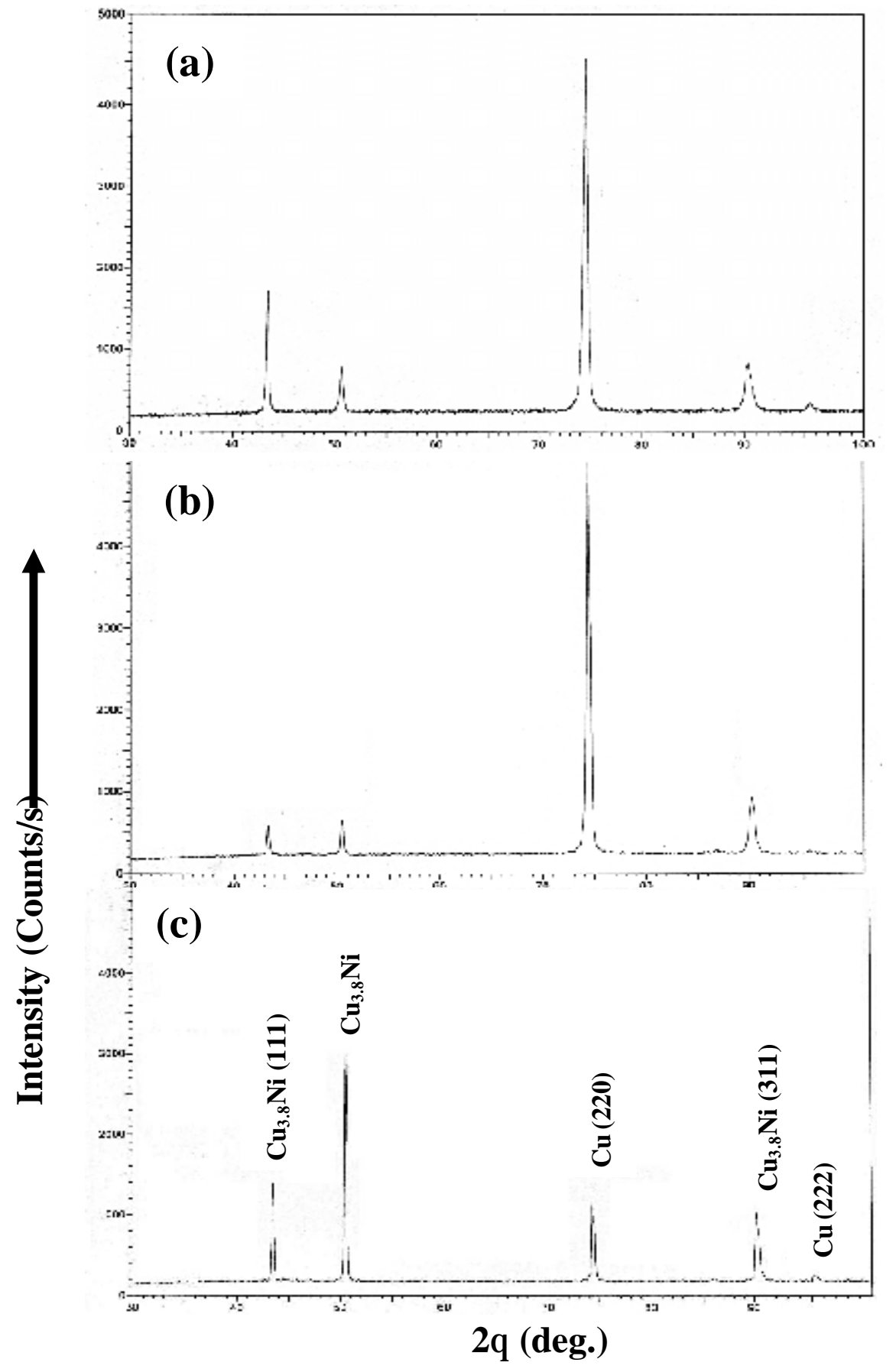

Fig. (5): X-ray diffraction patterns obtained for $\mathrm{Cu}-10 \mathrm{wt} . \% \mathrm{Ni}$ samples annealed for $1 \mathrm{~h}$ at different temperatures: (a) as-received; (b) $673 \mathrm{~K}$; (c) $1073 \mathrm{~K}$. 
Table (1): Values of average particle sizes of the $\mathrm{Cu}_{3.8} \mathrm{Niphaseobtained} \mathrm{for} \mathrm{the} \mathrm{as-}$ received and annealed samples at different annealing temperatures.

\begin{tabular}{|c|c|}
\hline Annealing Temperatures $(\mathrm{K})$ & Particle Size $(\mathrm{nm})$ \\
\hline As received & 23.8 \\
\hline 673 & 26.3 \\
\hline 1073 & 41.8 \\
\hline
\end{tabular}

\subsection{Energy Dispersive Spectroscopy (EDS)}

Spectrum of EDS was used to detect the elemental compositions for the $\mathrm{Cu}-10 \mathrm{wt} . \% \mathrm{Ni}$ samples before and after the sputtering process. Different zones were selected for each sample and the values of the elemental compositions given in Tables (2-4) are the average of at least ten measurements.

Table (2) gives the elemental compositions for the as-received Cu-10wt.\%Ni samples after being sputtered in a d.c. glow discharge for different times ( $1 \mathrm{~h}, 2 \mathrm{~h}$ and $3 \mathrm{~h}$ ). From this Table it can be concluded that increasing the sputtering time up to $3 \mathrm{~h}$ resulted in the increase of $\mathrm{Ni}$ content on the sample surface by approximately53\% compared with the unsputtered sample. This is due to the low sputtering yield of Ni element compared with that of $\mathrm{Cu}$. The ratio of the sputtering yields of pure $\mathrm{Ni}$ and $\mathrm{Cu}$ is $\frac{Y_{N i}}{Y_{\mathrm{Cu}}} \approx 0.65$ for $500 \mathrm{eVAr}^{+}$bombardment [26]. Furthermore, the increase of Ni content on the sample surface may be attributed to the high surface binding energy of $\mathrm{Ni}$ element which found to be $\approx 3.97 \pm 0.17 \mathrm{eV}$ compared with that of $\mathrm{Cu}$ element $(\approx 3.28 \pm 0.13 \mathrm{eV})[27]$.

Table (2): Elemental compositions for the as-received $\mathrm{Cu}-10 \mathrm{wt} . \% \mathrm{Ni}$ samples sputtered in an $\mathrm{Ar}^{+}$d.c. glow discharge for different sputtering times.

\begin{tabular}{|c|c|c|c|c|c|}
\hline \multirow{2}{*}{ Fig. 2. } & \multirow{2}{*}{$\begin{array}{c}\text { Sputtering } \\
\text { Time (h) }\end{array}$} & $\begin{array}{c}\text { Thickness of } \\
\text { Sputtered } \\
\text { Monolayer's (Á) }\end{array}$ & \multicolumn{2}{|c|}{$\begin{array}{c}\text { \% Elemental Composition } \\
\pm 0.05\end{array}$} & \multirow{2}{*}{$\begin{array}{c}\text { wt.\% gain } \\
\text { in Ni }\end{array}$} \\
\cline { 3 - 5 } & & & wt.\%Cu & wt.\%Ni & \\
\hline plate (a) & ---- & ---- & 90.02 & 9.98 & ---- \\
\hline plate (b) & 1 & 111600 & 88.98 & 11.02 & 1.04 \\
\hline plate (c) & 2 & 223200 & 85.48 & 14.52 & 4.54 \\
\hline plate (d) & 3 & 334800 & 84.75 & 15.25 & 5.27 \\
\hline
\end{tabular}


On the other hand, the elemental compositions for the $\mathrm{Cu}-10 \mathrm{wt} . \% \mathrm{Ni}$ samples being annealed for $1 \mathrm{~h}$ at different annealing temperatures (473, 673, 873 and $1073 \mathrm{~K})$ are given in Table (3). From this Table we concluded that increasing the annealing temperature up to $1073 \mathrm{~K}$ resulted in the increase of $\mathrm{Ni}$ content on the sample surface by approximately $24 \%$ compared with the as-received (unsputtered) sample. This increase of $\mathrm{Ni}$ content may be attributed to the fact that surface binding energy of $\mathrm{Cu}$ atoms is lessthan that of $\mathrm{Ni}$ atoms as mentioned earlier, therefore the $\mathrm{Cu}$ atoms (of high diffusivity) segregate faster towards the grain boundaries and the sample surface becomes enriched with $\mathrm{Ni}$ content. This explanationis in accordance with those obtained previously by other authors [28-31].

Table (3): Elemental compositions for the $\mathrm{Cu}-10 \mathrm{wt}$ \% Ni samples being annealed for $1 \mathrm{~h}$ at different annealing temperatures.

\begin{tabular}{|c|c|c|c|}
\hline \multirow{2}{*}{$\begin{array}{c}\text { Annealing } \\
\text { Temperature (K) }\end{array}$} & \multicolumn{2}{|c|}{ \% Elemental Composition \pm} & \multirow{2}{*}{ wt.\% gain in Ni } \\
\cline { 2 - 3 } & wt.\%Cu & wt.\%Ni & \\
\hline 473 & 89.98 & 10.02 & 0.04 \\
\hline 673 & 89.06 & 10.94 & 0.96 \\
\hline 873 & 88.91 & 11.09 & 1.11 \\
\hline 1073 & 87.66 & 12.34 & 2.36 \\
\hline
\end{tabular}

Furthermore, the elemental compositions for the annealed $\mathrm{Cu}-10 \mathrm{wt} . \% \mathrm{Ni}$ samples (mentioned in Table 3 ) followed by sputtering in a d.c. glow discharge for $3 \mathrm{~h}$ are given in Table (4). The data in Table (4) showed that sputtering the annealed samples for $3 \mathrm{~h}$ resulted in the increase of $\mathrm{Ni}$ content on the sample surface by approximately $32 \%$ compared with the asreceived (unsputtered) sample. The results obtained in this Table are referred to both growth of the $\mathrm{Cu}_{3.8} \mathrm{Ni}$ phase particles (which need more energy to be sputtered off) as well as the low sputtering yield of Ni particles due to the combined effect of both annealing temperature and ion bombardment. These lead to presence of more Ni content on the sample surface.

These information shade light on the important role of ion bombardment on increasing $\mathrm{Ni}$ content in the studied alloy than that of annealing temperature. This increase of $\mathrm{Ni}$ content on the sample surface either due to ion bombardment or annealing temperature significantly improves the resistance of the given alloy to erosion corrosion in flowing seawater and other aggressive waters. 
Table (4): Elemental compositions for annealed $\mathrm{Cu}-10 \mathrm{wt} . \% \mathrm{Ni}$ samples sputtered in an $\mathrm{Ar}^{+}$d.c. glow discharge for $3 \mathrm{~h}$.

\begin{tabular}{|c|c|c|c|c|}
\hline \multirow{2}{*}{ Fig. 4. } & \multirow{2}{*}{$\begin{array}{c}\text { Sputtering } \\
\text { Time (h) }\end{array}$} & \multicolumn{2}{|c|}{ \% Elemental Composition \pm 0.05} & \multirow{2}{*}{ wt.\% gain in Ni } \\
\cline { 3 - 4 } & & wt.\% $\mathrm{Cu}$ & wt.\% Ni & \\
\hline plate (a) & 3 & 87.7 & 12.30 & 2.32 \\
\hline plate (b) & 3 & 87.67 & 12.33 & 2.35 \\
\hline plate (c) & 3 & 87.19 & 12.81 & 2.83 \\
\hline plate (d) & 3 & 86.83 & 13.17 & 3.19 \\
\hline
\end{tabular}

\subsection{Hardness Measurements}

The Vickers hardness number $\left(\mathrm{H}_{\mathrm{V}}\right)$ of the different annealed samples was measured as a function of annealing temperature. The results obtained are shown in Fig. (6), from which it is clear that $\mathrm{H}_{\mathrm{V}}$ decreases slightly with increasing annealing temperature up to $673 \mathrm{~K}$ then decreases significantly

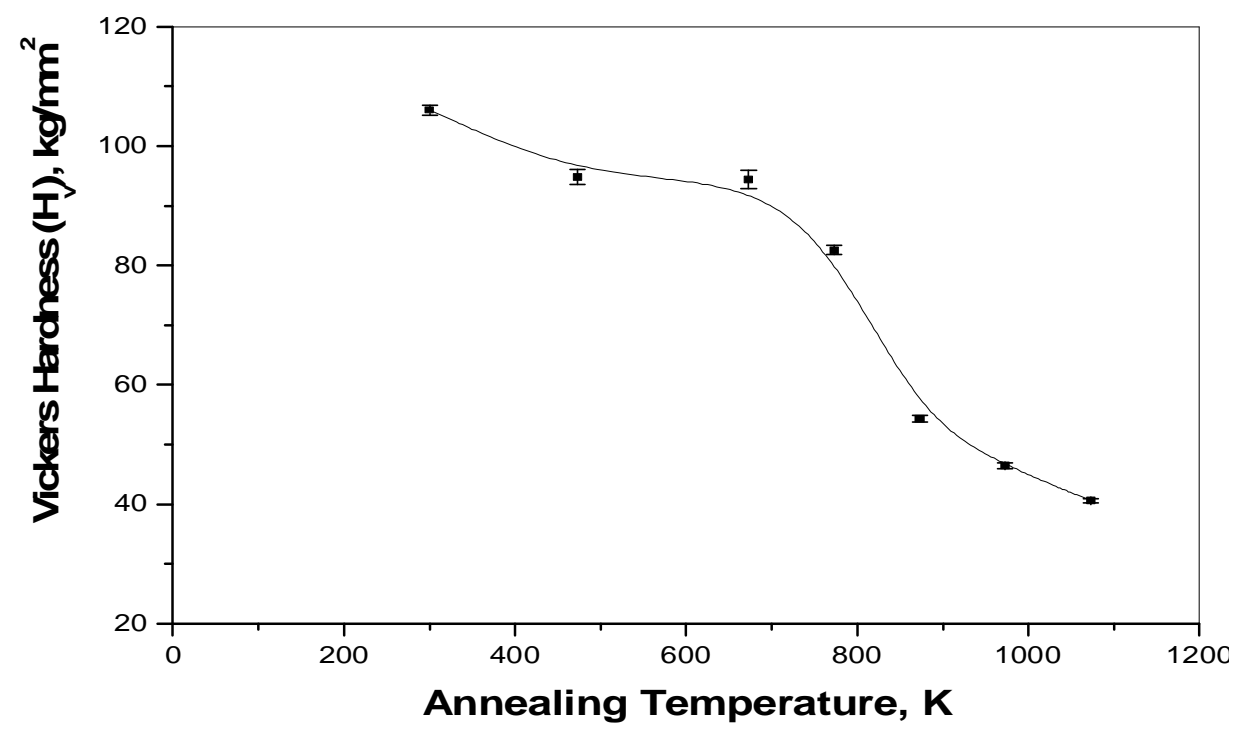

with further increase in temperature up to $1073 \mathrm{~K}$.

Fig. (6): Change of hardness value with annealing temperature.

The slight decrease in the material hardness with increasing annealing temperature up to $673 \mathrm{~K}$ may be attributed to the slight increase in the average particle sizes of $\mathrm{Cu}_{3.8}$ Niphase from $23.8 \mathrm{~nm}$ to $26.3 \mathrm{~nm}$ as shown in Table (1). On the other hand, the significant decrease in the material hardness with increasing annealing temperature above $673 \mathrm{~K}$ may be attributed to the decrease of both crystal imperfections [22] and/ or density of tiny 
$\mathrm{Cu}_{3.8}$ Niphase particles (due to their growth). These results are supported by the data shown in Table (1), which shows that the average particle sizes of $\mathrm{Cu}_{3.8} \mathrm{Niphase}$ are significantly increased from $26.3 \mathrm{~nm}$ to $41.8 \mathrm{~nm}$ as the annealing temperature increased from $673 \mathrm{~K}$ to $1073 \mathrm{~K}$, respectively.

\section{Conclusions:}

Effects of physical sputtering and annealing temperature on surface topography and composition of $\mathrm{Cu}-10 \mathrm{wt} . \% \mathrm{Ni}$ alloy as well as its hardnessare considered. The main conclusions from this study are :

- Sputtering the as-received samples increases the Ni content on the alloy surface by approximately $53 \%$ compared with the unsputtered sample, while sputtering the annealed samples increases the $\mathrm{Ni}$ content by approximately $32 \%$.

- Sputtering the as-received samples produces fine surface structure, while sputtering the annealed samples produces irregular surfaces associated with the appearance of large cones and etch pits.

- Thickness of sputtered material per second per $\mathrm{cm}^{2}$ of the given alloy was found to be approximately $31 \AA$.

- Hardness of the given alloy is found to be of a high average value in the temperature range $(300-673 \mathrm{~K})$ followed by a sharp decrease in its value above $673 \mathrm{~K}$.

\section{References:}

1. E.G. West, "Copper and Its Alloys", Ellis Horwood Ltd., Halsted Press, New York, NY, USA, (1982).

2. B.V. AppaRao, K.Chaitanya Kumar, J. Mater. Sci. Technol. 30, 65 (2014).

3. F.Pawlek, Metallhtlenkunde, Walter de Gruyter, Berlin-New York (1983)

4. J.Y. Song, S.I.Hong, Materials and Design, 32, 1790 (2011).

5. C.A.Powell, "Preventing biofouling with copper alloys", CDA Publication 157, October (2002).

6. K.D.Efird, Materials Performance, 15, 16 (1976).

7. K.D.Efird, D.B.Anderson, Materials Performance, 33, 37 (1975).

8. D.T.Peters, H.T.Michels, C.A.Powell, Galveston, Texas. (1999) 189, Houston Texas, (2000).

9. C.A.Powell, Corrosion and Biofouling Protection of Ship Hulls Using Copper-Nickel, Proceedings of International Conference on Marine Corrosion Prevention, London, UK, (1994). 
10. C.N. Tharamani, S.M. Mayanna, Solar Energy Materials \& Solar Cells, 91, 664 (2007).

11. D.G. Melton, OTC, Houston-Texas, May, 6, 221 (1991).

12. W.Kirk, Evaluation of Critical Seawater Hydrodynamics Effects of Erosion Corrosion of Copper-Nickel, INCRA Report 396 (1987).

13. T.Glover, Copper-Nickel Alloys for the Construction of Ship and Boat Hulls, British Corrosion Journal, 17, 155 (1982).

14. D.Jordan and C.A.Powell, Fabrication of Copper-Nickel Alloys for Offshore Applications, Welding in Maritime Engineering Symposium, KrK, Croatia, October, 22-24, (1998).

15. L.Boulton, W.Hudson and C.A.Powell, Controlling Biofouling on Ferry Hulls with Copper-Nickel, $10^{\text {th }}$ International Congress on Marine Corrosion and Fouling, Feb (1999), Melbourne.

16. Ullmann's Encyclopedia of Industrial Chemistry, Fifth Edition, Weinheim (1986).

17. K. Nakayama, M.Ono, H.Shimizu, Journal of Vacuum Science and Technology, 9, 749 (1972).

18. Y.Takasu, H.Shimizu, Journal of Catalysis, 29, 479 (1973).

19. H.Shimizu, M.Ono, K.Nakayama, Journal of Applied Physics, 46, 460 (1975).

20. F.J.Kuijers, V.Ponec, Surface Science, 68, 294 (1977).

21. H.Shimizu,M.Ono, N.Koyama, Y.Ishida, Journal of Applied Physics, 53, 3044 (1982).

22. G.Graiss, G.Saad, A.Fawzy, M.A.Kenawy, Gzechoslovak, J. Phys, 41, 149 (1991).

23. G.Petzow, Metallographic Etching, American Society for Metals, 59 (1978)

24. S.K. Habib, A. Rizk, I.A. Mousa, Vacuum, 49,153 (1998).

25. B.D.Cullity, Elements of X-ray Diffractions, second edition, AddisonWesley Publishing Company, Inc. 284 (1978).

26. G.Carter and J.S.Colligon, Ion Bombardment of Solids, New York, Elsevier; (1968).

27. N.Q. Lam, K. Johannessen, Nuclear Instruments and Methods in Physics Research, B 71, 371 (1992).

28. Y.Teraoka, M.Komaki, Surface Science, 439, 1 (1999).

29. G.N.Deny, Surface Segregation in Binary Metal Alloys, Handbook of Surfaces and Interfaces of Materials, 1, 329 (2001).

30. S.Divinski, J.Ribbe, G.Schmitz, Ch.Herzig, ActaMaterialia, 55, 3337 (2007).

31. L.Zhang, G.Tang, X.Maa, F. M. Russell, X.Cao, B.Wang, P.Zhang, Physics Letters, A375, 1976 (2011). 